\title{
'More-than-human' resilience(s)? Enhancing community in Finnish forest farms
}

Article

Accepted Version

Herman, A. (2016) 'More-than-human' resilience(s)?

Enhancing community in Finnish forest farms. Geoforum, 69. pp. 34-43. ISSN 0016-7185 doi:

https://doi.org/10.1016/j.geoforum.2015.12.005 Available at https://centaur.reading.ac.uk/57620/

It is advisable to refer to the publisher's version if you intend to cite from the work. See Guidance on citing.

To link to this article DOI: http://dx.doi.org/10.1016/j.geoforum.2015.12.005

Publisher: Elsevier

All outputs in CentAUR are protected by Intellectual Property Rights law, including copyright law. Copyright and IPR is retained by the creators or other copyright holders. Terms and conditions for use of this material are defined in the End User Agreement.

www.reading.ac.uk/centaur 
Central Archive at the University of Reading

Reading's research outputs online 


\section{'More-than-human' Resilience(s)? Enhancing Community in Finnish Forest Farms}

\section{Introduction}

'Lately resilience has become the answer to everything' (Diprose, 2014: 44)

Resilience, like sustainability, empowerment and a host of other concepts, seems easy to dismiss as yet another ambiguous buzzword that is deployed in multiple ways by varying actants (Brassett et al., 2013). Yet, despite increasing critique regarding its depoliticised, catch-all nature and obliviousness to inequality (Brassett et al., 2013; Diprose, 2014; Fainstein, 2015), it remains a useful tool to explore and analyse experiences of complexity and unpredictability (Coward, 2015), and engage with processes of change (Wilson, 2015). In spite of the wide variety and backgrounds to its usage, common motifs in definitions of resilience centre around the capacity of an individual/community/organisation/system to sustain and adapt to disturbances and change while retaining essentially the same identity, structure, function and relations (Adger et al., 2011; Fainstein, 2015).

Nevertheless, for critics resilience ultimately remains futile because it instils inequality, re-locates responsibility from the state to 'active citizens' and so devolves risk and defers demands for change (Diprose, 2014). Evans and Reid (2013: 93) argue that 'social responsibility [is] replaced by a neoliberalised care for the self' as the resilient subject is forced to live with insecurity. Resilience therefore becomes a nihilistic form of neoliberal interventionism, which forces the subject to abandon the political (ibid), and the maintenance of 'business as usual' offers no basis for contentious politics or the pursuit of social justice (Diprose, 2014). This highlights the now hegemonic theoretical connection of neoliberalism and resilience (see Hall and Lamont, 2013; Howell, 2015; Joseph, 2013; Reid, 2012; Rogers, 2013). This paper responds to Anderson's (2015) 
call to question this assumed linkage, which he argues supports repetitive critiques in which we always already know the consequences and politics. Instead 'there is not and never has been one "resilient subject"' (ibid: 61) and the common, and homogenising, utilisation of an ideal type 'resilience' obscures the uneven and varying spatialities and temporalities of different resiliences.

Social resilience is the ability of individuals and communities to cope with disturbances, and the ways in which they adapt, transform and 'potentially become stronger' (Maclean et al., 2014: 146) in the face of socio-economic, political or environmental challenges (Adger, 2000). Despite the increasing interest in resilience, and recognition of the interconnected nature of the social and environmental, research has predominantly focused on the latter (Maclean et al., 2014); while this is changing (see Berkes and Ross, 2013; Keck and Sakdapolrak, 2013; Magis, 2010), more work is needed to better understand this important and interdisciplinary concept. This paper contributes to this project by offering an original analysis against the individualising tendencies of the hegemonic neoliberal-resilience assemblage (Anderson, 2015); through a focus on community networks, which are widely identified as critical to achieving social resilience, (Aldrich and Meyer, 2015; Krøvel, 2014; Wilson, 2015) it positions the latter as collective.

Agriculture is an important area in which to explore these meanings of resilience because it is a critical global sector characterised by volatility and unpredictability. It is essential for both farmers' management strategies and governmental policy to understand to what extent and how farms are resilient within the contemporary context of climate instability, land degradation, changing governmental regulations, volatile commodity prices and the restructuring of the global agri-food regime (Cadieux and Blumberg, 2013). Farms are complex and contingent systems composed of multiple and dynamic relations between, amongst others, owners, workers, animals, plants, technologies, soil, weather, buildings, unions, water, government departments and 
chemicals (Latour, 1993, 2005). I would therefore argue that they are best conceptualized as relational and collective 'more-than-human' entanglements that reflect the agency of both the human and nonhuman actants within these systems. More-than-human and post-human theorists offer various ways to conceptualise the 'socio-material', and work on assemblages is particularly useful because its 'account of different ways in which orders endure across difference and amid transformation' (Anderson et al., 2012: 173) connects into similar discussions around resilience. Acknowledging the diversity of understandings of 'assemblage', here it is positioned as an ongoing process of composition across and through human and nonhuman actants that recognises the agency of both the parts and the whole (ibid). While having similarities to actor network theory (ANT), the latter's focus on 'associations' rather than the 'relations of exteriority' of an assemblage have been criticised with ANT positioned as 'blind to what remains outside associations but may shape them nevertheless' (Müller, 2015: 31). Assemblage thinking therefore offers 'an ethos for thinking the relations between durability and transformation' (Anderson et al., 2012: 180) and, when combined with the normative framework of a more-than-human lens, offers a useful tool through which to explore social resilience.

Research on agricultural resilience has, to date, largely focused on economic and policy implications and mechanisms (Hammond et al., 2013; Maleksaeidi and Karami, 2013; Ranjan, 2014) or agro-ecological management (Björklund et al., 2012; Lin, 2011), which often fails to take account of the embodied and immersive nature of farming as a lifestyle and livelihood. However, there is a wealth of rural sociology, geography and anthropology exploring the socio-cultures of agriculture, which is increasingly being drawn on to explicitly focus on social resilience, for example through mental health (Alston, 2012; Greenhill et al., 2009; Hunt et al., 2011), farm conversion and succession (Forney and Stock, 2014), transformational capacity (Marshall et al., 2012) and ANT (Dwiartama and Rosin, 2014). Nevertheless, there remains a strong, humanist 
focus to much of this work, which this paper builds on to more inclusively embed resilience within a more-than-human context and so more fully acknowledge the complex socio-cultural assemblages within which all farmers are enmeshed.

The paper begins by arguing that we need a broad understanding of the 'social' in order to recognize that communities, such as farms, are co-constructed assemblages of humans and nonhumans. It then builds on the concept of community resilience, using an engagement with the more-than-human literatures, to develop a conceptualisation of social resilience as relational, contextual and performed. Drawing on the 16 semi-structured interviews of an exploratory case study conducted in 2014 with Finnish farmers and industry stakeholders, the paper then empirically explores this 'more-than-human resilience' through a focus on forests. In Finland, all farms practise forestry (Hyttinen and Kola, 1995; Väre, 2007) and so this presents a shared morethan-human actant across Finnish agriculture. The paper analyses how the forest develops, maintains and enhances community networks through relations and practices of connection, management and security. Finland presents an interesting case study because its late development as an industrial and urban nation is unique within the European context (Silvasti, 2003a), and offers a contrast to the larger-scale agricultures and more distant rural heritages of the UK and USA, which dominate rural research (McDonagh, 2012). This paper therefore also works to extend the scope of rural scholarship. It concludes that the more-than-human allows for a more fractured and multiple conceptualization of resiliences, which helps to bridge the socioecological divide that persists within resilience thinking and makes space for justice through encouraging the recognition of a co-fabricated, co-constituted and expansive 'social'. 


\section{The More-than-Human Farm: practices and relations of community}

Community, like resilience, is a contested term with multiple definitions and critiques demanding recognition of its overlapping, changeable and exclusionary nature, which is always embedded within complex networks of power (Wilson, 2015). Broadly, 'community' may be conceptualized as a group of individuals with shared geographical, social, political, economic or cultural characteristics. However, more-than-human literatures have highlighted that social relations are always structured through human-nonhuman networks (Nimmo, 2011), reminding us that the domain of the social is a contingent, co-constitutive and interdependent assemblage of human and nonhuman actants, relations, practices and discourses (Latour, 2005). Communities, as a key scale at which societies are organized and operate, therefore must be constituted by similarly complex and dynamic networks. I explore this here through a focus on 'the farm', a key element of and within rural communities, considering how this is shaped through more-than-human interrelationships. The majority of more-than-human literatures have focused on how animals impact on human ideas and communities (Johnston, 2008) and are significant in constituting both place and identity (Holloway, 2001; Sellick and Yarwood, 2013). Given its significance, I use this body of work to reflect on the more-than-human farm; however, as we will see in Section 5, livestock are not the only, or always central, actants on farms. Nonetheless, the work on animals prompts a critical engagement with the non-animal and can be used to inform understandings of the interrelationships between humans and the non-intentioning, yet active, 'planty' non-human.

For Holloway (2002: 2057) 'farming becomes an ordering of land, animals, people etc. which produces 'the farm' as an effect of a network'. The role of non-humans in such rural networks as 'ecosystem engineers' is emphasized when the "'taken for granted" social, cultural and economic interactions between humans, livestock and landscapes' (Convery et al., 2005: 100) are disturbed 
by, for example, the impacts of disease (Sellick and Yarwood, 2013). The assemblages of farmers and livestock in particular places are locally and historically grounded (Holloway and Morris, 2014; Yarwood and Evans, 2006), and form interconnected and internally reinforcing farming cultures (Gray, 1996) that govern how farmers engage with the nonhuman elements of their farms and what being a 'good farmer' entails (Burton, 2012; Holloway, 2002; Silvasti, 2003a). We need to recognise the agency of such symbolic, moral or discursive elements in terms of understanding what constitutes and shapes a farm community (Krarup and Blok, 2011); as seen in changing discourses around breed characteristics (Holloway and Morris, 2014) or 'ethical' agriculture (Holloway, 2002), the farm is a constant work in progress informed by changing socio-cultural, political, economic and environmental drivers, which requires constant performance and (re)construction in different contexts, times and places (Riley, 2011).

Animals emerge as active participants in making the places, relations and practices that form the more-than-human communities of the farm. Riley (2011) notes how continual and active corporeal engagement with animals is key to acceptance and membership within livestock farming communities, and how daily interactions with animals can foster a sense of belonging that is spatially as well as temporally inflected. Past practices can provide a blueprint for current activities (Riley, 2008, 2011) but animals themselves can embody the farm history, performing the successful (or not) operation and succession of the farm. Animals are inscribed with the efforts of several generations and so connect the past, present and future of a particular farm community (Convery et al., 2005; Yarwood and Evans, 2006). Here, 'community' emerges as an everyday and practiced 'taskscape' (Ingold, 1993) of connection, identity and interaction for both human and nonhuman actants, which may be experienced in a particular place - the farm, the showground, the market - but connects into wider spaces, times and networks. 
Within these communities we cannot deny the differences between human and nonhuman actants (Bennett, 2004), which is encapsulated in Latimer's (2013) conceptualisation of this relation as a 'being alongside', which retains the differences and potential tensions that may exist within this. Humans and nonhumans are always operating in a context of asymmetrical power relations, which demand that we question who or what is benefitting from any particular practice, and how we can give voice to the nonhuman without imposing more of our human selves in the process (Head and Atchison, 2008). Bear (2011) argues that in order to move animals from the shadows we need to stop speaking of them as collectives and re-focus on the individual, although more individual 'meetings' may exacerbate the feeling that the being we meet is, and shall always be, strange to us (Morton, 2010). However, as Phillips (2014) argues, a feeling of nonhuman difference can lead to ethical distance but, equally, can induce a fascination, or enchantment, that fosters a long-term desire for in-depth engagement and encourages more responsible praxis. Phillips (2014) notes that the performance of human-nonhuman relations helps to establish attachments to particular places; 'intimate practice can move well beyond the boundaries of any one relation' highlighting the 'multi-species, multi-sited, multigenerational' relations that emerge through these more-than-human entanglements (Phillips, 2014: 157).

Clearly more-than-human farm communities consist of active players beyond these animal actants. While 'plants are easy to take for granted' (Head and Atchison, 2008: 2) they also have agency and can act to link people and places, embedding geographically defined communities in particular spaces through co-producing identity and belonging in interconnected and coconstitutive ways (Jones, 2011). As Head and Atchison (2008: 1) comment 'plants are fundamental players in human lives... and vice versa' but they have an even more ghost-like presence in the social than animals (Jones and Cloke, 2002) because there is a greater ethical distance between plants and humans. Trees are one exception to this rule, being 'particularly 
susceptible to imaginative social and cultural constructions' (Cloke and Pawson, 2008: 109), because 'as a species we have grown up with and within trees and forests...[and through which] the continuities of time and place are made visible, immediate...tangible' (Jones, 2011: 161-162). Trees - like livestock - therefore play a special role in the liveability of communities (Zhang et al., 2007) as they embody past practices and carry memories into the present with their materiality impacting directly on the meaningfulness of a place, and how it is performed and experienced (Cloke and Pawson, 2008). However, echoing Bear's (2011) critique, plants too tend to be considered as a collective rather than as individuals (Head and Atchison, 2008). This lack of ethical standing is exacerbated by their transformability as they become food or biofuels, which arguably increases the distance between the user and the original plant. While this can make production processes more transparent, foregrounding questions of ethics around these conditions, this alienation prevents similar concern for the plant(s) (Head and Atchison, 2008).

The inclusivity of a more-than-human social, explored here through the practices and affects of animals and plants as active agents within communities, enables us to recognize a broader range of relations and networks, which can strengthen or weaken the identity, collaboration and cohesion of a community. As Wilson (2015: 230) comments communities are 'continuously and simultaneously affected by several disturbances at any point in time', meaning that they must therefore constantly work to be resilient.

\section{Community Resilience in a More-than-Human World}

'Community resilience is the existence, development and engagement of community resources by community members to thrive in an environment characterized by change, uncertainty, unpredictability, and surprise' 
Despite widespread recognition of 'community' as a problematic and contested concept (Wilson, 2010), its positioning as a key scale at which social resilience is implemented has led to increasing attention to the concept of 'community resilience', addressing the previous neglect of this scale of analysis (see Berkes and Ross, 2013; Krøvel, 2014; Magis, 2010; Robinson and Berkes, 2011; Wilson, 2015). Community resilience centres around the capability of a 'community' to deal with stressors and 'resume the rhythms of daily life' (Aldrich and Meyer, 2015: 255). As with resilience more broadly, definitional and measurement issues abound (Anderson, 2015) although community networks - 'the social processes and activities that support people and groups in a place' (Maclean et al., 2014: 149) - and community resources are common attributes (Aldrich and Meyer, 2015; Berkes and Ross, 2013; Magis, 2010; Wilson, 2015). Resources refer to a diverse range of economic, political, social, cultural, natural and built elements, which must be developed and used; it is not enough to have the capacity to act (Magis, 2010), community resilience is facilitated by an active engagement with the community's resources. It is therefore a collective process rather than an outcome (Berkes and Ross, 2013), a position that recognizes that communities themselves are never stable (Wilson, 2015). This acknowledges a key difference between social and ecological systems: change, not stasis, is the constant here because learning and social memory mean that a human system can never revert back to some 'original' state (Folke et al., 2003; Magis, 2010).

Social resilience is therefore something that is practiced within a messy, complex and unpredictable world (Krøvel, 2014) and, while equitable flourishing of all members of the community may be the aim (Mason and Pulvirenti, 2013), uneven power relations mean that community members will neither be equally exposed to a disturbance nor have an equal capacity 
to participate. A common assumption is that everyone will benefit if the resilience of a community is enhanced (Fainstein, 2015) because this is a multi-scalar, multidimensional and co-produced process (Berkes and Ross, 2013; Krøvel, 2014; Mason and Pulvirenti, 2013) but the often highly divergent aims and complex power networks within communities (Wilson, 2010) mean that resilience-building strategies may be exclusionary. This paper addresses one exclusion innate to current conceptualisations of community resilience. While resilience literatures recognize the complex interconnections between human and ecological systems (Folke, 2006), where are the nonhuman actants? The importance assigned to 'active agency' within social resilience literatures has assigned nonhumans a passive role since 'only humans anticipate change and use social, political, and cultural means to influence resilience' (Berkes and Ross, 2013: 16).

In contrast to this anthropocentric understanding, to more-than-human scholars humans are 'enmeshed with rather than outside nonhuman nature' (Head and Muir, 2006: 510) and so:

"who "we" are is relationally constituted and dependent upon links that stretch far beyond ourselves in time and space, to places and beings wholly other to what we see as that which constitutes our proper selves' (Metzger, 2014: 1008)

This demands a reassessment of agency, which becomes relocated in practice rather than discourse with 'the intentioning subject no longer conflated with causality' (Dixon, 2009: 414). The severing of this link establishes agency as an emergent property, a relational effect of the assemblages of humans and nonhumans, partial connections and intermittent attachments that constitute a more-than-human world (Latimer and Miele, 2013; Nimmo, 2011). This is an integrated, intersecting, co-constituted, clashing, collaborative and co-dependent space (Panelli, 2010) in which agency is a continuum, a power that is differentially expressed by all material bodies (Latour, 1999). Bennett (2004) argues that while we must acknowledge the shared 
material basis of all human or nonhuman things, this does not deny the differences or asymmetrical power relations that exist between them (Latimer and Miele, 2013). However, recognizing our material and relational nature arguably establishes a greater sense of interconnection and so encourages ethical action through 'enlightened self-interest' (Bennett, 2004: 361).

Chandler (2013) argues that such associational connectivity is pushing agency onto the everyday, self-reflexivity of the individual, which makes us responsible for the world but only able to take action through working on our own self-growth. However, if agency is relational and collective (Dwiartama and Rosin, 2014), resilience is no longer solely dependent on our intentional actions. When resilience is similarly understood as a relational and emergent property, actions that deliberately attempt to develop and enhance it are found alongside those that are responding to the unexpected events triggered by an active but not intentioning (non)human. This highlights the contextuality and dynamism of resilience, which must be constantly performed through evershifting relations and environments (Dwiartama and Rosin, 2014; Latimer and Miele, 2013). This both emphasizes the multiplicity of different resiliences between, and within, contexts, and decentres the individual in our focus, who becomes positioned as part of a networked assemblage. An individual may still choose to undertake 'self-growth' but this now depends on action across the multiple relations that constitute this 'self'.

This promotes an ethical response through foregrounding the intimate connections between care for both humans and the nonhuman' (Lawson, 2007: 6) in what Ginn (2014) terms a 'contagion' model of ethics. A joyful focus on connectivity, vitality and belonging can obscure as much as it reveals and so Ginn (2014) asks what of the nonhumans we relate to only through a "hoped-for absence'? How do we acknowledge the exclusions that also create particular places? To Ginn 
(2014) it is the space beyond relations that creates the opportunity for inter-species ethics through detachment but this still connects us with those we want to exclude. We continue to respond to their presence/absence, anticipating their movements and dealing with the unpredictable nature of our encounters. More-than-human resiliences demand that we are responsive to all the relations, whether of connection or detachment, that constitute our selfassemblages. Ginn (2014) highlights the complex and unpredictable networks and communities that constitute a place, reminding us that 'we tend to limit the social to humans and modern societies, forgetting that the domain of the social is much more extensive that that' (Latour, 2005: 6). The inclusivity of a more-than-human social, and recognition of our entangled intersubjectivity, promotes a relational understanding of ethics (Massey, 2004; Popke, 2006) in which individual ethical responsibility is already enmeshed within practices of collective, multiscale responsibility (Barnett et al., 2005). It is clear that nonhumans do not intentionally contribute to resilience; instead, it is through their actions and relations with each other and humans that relations, practices, opportunities and things emerge that can enhance the resilience (or vulnerability) of the community. This constant performance connects into Puig de la Bellacasa's (2010) approach to ethics as an everyday doing. Through this she 'connects the personal to the collective and decentres the human, as well as grounding ethical obligation in concrete relationalities in the making' (ibid: 152). To paraphrase, resilience emerges as 'embedded in the practices that maintain the webs of relationality that we form' (ibid: 167) and are formed by, so in the very 'inter' of our interconnections and interactions (Schmidt, 2013).

Resilience appears in this account as a lucky coincidence but while the intentional agency of humans may have been decentred to make space for the random 'thing-power' of things (Bennett, 2004), this does not negate the possibility of, or indeed potential need for, deliberate practices to steer a community along a resilient path. Although humans may no longer be at the centre of 
things, this 'does not excuse humanity from thinking about its position in the context of a wider set of relations with the rest of nature; rather it heightens this responsibility' (Cudworth and Hobden, 2015: 136). Furthermore, resilience is not always positive and may be specific to only one element of the system, at the expense of others and the resilience of the system as a whole (Folke et al., 2010). Given that it is a systems concept (Folke et al., 2010) and emergent through the relations and properties of this system (Day, 2014), resilience is therefore dependent on the interactions between all of its members, and so in turn their individual capabilities (which shape these relations of resilience or vulnerability) must be supported and enhanced. A resilient agent contributes to the resilience of the community as a whole (Berkes and Ross, 2013); therefore, through acknowledging its dynamism, contextuality and relationality, a more inclusive and ethically grounded more-than-human resilience emerges.

\section{Research Context}

This paper draws on an exploratory pilot project, which involved 16 semi-structured interviews with farmers from the Etelä-Savo and Kymenlaakso regions of Southern Finland and representatives of national and regional agricultural institutions, as well as policy documents from NGOs, unions and government bodies. All interviews were conducted in April 2014. The key governmental and non-governmental stakeholders in these regions were identified from policy literatures as the Ministry of Agriculture, Forestry and Fisheries (MMM), MTK (the central union of agricultural producers and forest owners), Saimaan Luomo (a regional organic organization) and Evira (the national organic certifier), and representatives from each were interviewed. The original focus of the research was to explore the interactions and impacts of the multiple socioeconomic, environmental and political imperatives at work within Finnish agriculture, and so 
interviews focused on the challenges faced, responses and strategies for the future. The study recognised the potentially different pressures exerted by various regulatory systems and aimed to explore these through a comparison of the experiences of organic and conventional producers, although the limited sample size meant that this was not possible.

Both Etelä-Savo and Kymenlaakso are heavily forested but, being in the south-east of Finland, have relatively favourable climates for agricultural production. While there are producers of all types in both regions, Kymenlaakso has a higher proportion of arable land producing both fodder and food crops, while Etelä-Savo has more dairy and meat production. Farmers were recruited through contacts at the Ruralia Institute, University of Helsinki, and, while the potential sample was limited to those confident speaking English, it included a range of farmers (four arable, two vegetable, four dairy and two mixed producers) and farm sizes (11-290 hectares) reflective of the type of farming in these regions. As is common in Finland, all farms also practiced forestry (Hyttinen and Kola, 1995; Väre, 2007) with forest holdings ranging from 16 to 197 hectares.

Given the time constraints of conducting interviews on working farms, field observations were only possible on one farm but anecdotal evidence and discussions with Finnish colleagues helped develop the ideas about the role of the forest within the Finnish farm. Despite the small sample size, this allowed for a relatively broad and comparative understanding of the farmers' connections within the farm assemblage, the challenges they faced and their strategies to be(come) resilient, although as an exploratory study the wider applicability of the findings cannot be asserted. However, it offers some interesting insights for further discussions and research around social and community resiliences. 
Finnish farmers have long faced environmental, economic, political and social challenges but their relative uncompetitiveness, and the consequent need for structural reform, only became apparent on joining the European Union (EU) in 1995 (Väre, 2007):

'...only $8 \%$ of the land area is farmland...the growing season is short...on the European scale the average yields of arable farming are very low...the building costs of livestock buildings, warehouses and manure storage facilities are very high...[it is] difficult to create larger uniform arable land areas. The small size and scattered location of [land] parcels cause additional costs to farming and make it difficult to increase the farm size. Often there are different types of soil... which is why fertilisation may be difficult to plan... [and] the final crop is not of uniform quality'

MMM (2007)

Despite these issues, agriculture and forestry remained central to the Finnish economy for a long time (Solsten and Meditz, 1988); indeed, Finland's very recent rural heritage has resulted in a deep and persistent "peasant culture" (Buciega et al., 2009; Silvasti, 2003a) in which continuity of the family farm is the central objective (Silvasti, 2003b). However, since joining the EU, Finland has experienced trends, echoed across Europe, of increasing farm size, decreasing number of farms, increasing average age of farmers and decreasing number of farm transfers (Hietala-Koivu, 2002; Väre, 2007) that are impacting on the achievement of this social script. While the MMM (2013) argues that the EU's Common Agricultural Policy (CAP) has enhanced agricultural competitiveness, since 1995 a growing share of farm income has come from EU or national support payments. According to the MMM (2011) $29 \%$ is earned behind a desk rather than in the field, conflicting with what Finnish farmers consider to constitute 'good' farming (Silvasti, 2003a). Finland receives a higher value of EU subsidies than its relative weight in agricultural output value (Eurostat, 2013) 
because of low productivity (Pouta et al., 2011) and rural depopulation (MMM, 2011). Within Finland the key objectives of CAP are therefore interpreted as 'preserving sustainable food production based on family farming' and 'preserving the viability of rural areas and promoting balanced regional development' (MMM, 2013). Agriculture consequently remains important and, combined with the continuing script of continuity (Silvasti, 2003b), this offers compelling political and social motivations for Finnish farmers to be(come) resilient.

\section{Practising Resilience: assembling the forest}

Dwiartama and Rosin (2014: 35) argue that '...the ability of humans to... build resilience is dependent upon the specific relations between them and the nonhuman component', and this paper could have focused on the technologies, discourses, insects, pathogens, livestock or any of the other nonhumans that inflected the farmers' conversations. However, the forest emerged as a particularly important actant across all the farms of this exploratory study. While the trees themselves do not intentionally or actively work towards resilience, this reflects not passivity but a more varied, subtle, multi-scalar and inter-temporal repertoire of capacities for action (Brice, 2014). The collective of the 'Finnish farm', of which the forest forms a part, can hold together in shifting, contextual and practised ways across and through differences, ensuring the resilience or

vulnerability of a farm. Nonetheless, while each farming community holds particular ideals of what constitutes the desired farmscape to be preserved, this does not preclude the possibility of other formations. Therefore, in order to understand the Finnish farm, we must first consider the historic production of the forest nested within and through it; how is the Finnish forest assembled and held in place, and how does it work to open up, or close down, the possibilities for resilience of the farm community as a whole? 
While the majority of farms in Finland own forest, around $20 \%$ of the Finnish population more broadly are also forest owners (Vainio and Paloniemi, 2012). Jones (2011: 160) argues that forests 'create powerful landscapes which can enclose the person, enclose whole communities, even nations' and in Finland, the forest has long been considered a key source of national well-being (Sarkki and Rönkä, 2012). This position was arguably strengthened by its central position in Finland's independence, which was initially supported economically almost entirely through its forest industries (Kotilainen and Rytteri, 2011). The forest is therefore key in 'enclosing' Finland's national identity and so connections to the forest are commonly positioned as important elements of 'Finnish-ness' (Pentikainen, 1995); one arable farmer, in recounting his family's farming history, noted that following the post-WWII border changes with Russia, resettled farmers were granted areas of both field and forest. Forests therefore represent important spaces in both farm and broader rural communities, connecting farmers into strong discourses of national identity, and so identifying them through their ownership and practices as specifically Finnish farmers.

Following Foucault, all discourses are grounded in the particular contexts and power relations of their times and a 'forest' is a similarly historic production (DeLanda, 2006), being shaped by the cultural, economic, political and social environments through which it grows as a biological ecosystem. Forests emerged in the accounts of the Finnish farmers as places of connection, management and/or security highlighting that they were understood not as biological entities but as social constructs, with their materiality only discussed in terms of how it was experienced. This hints towards their 'planty agency', which emerges through the 'associations, practices and encounters within which changes in plants affect, displace and transform human bodies and conduct' (Brice, 2014: 946); through exploring how forests are assembled as places of connection, management or security, their co-constitutive relationship with human practices emerges. 


\section{A. The Forest as a Place of Temporal Connection}

The forest offered a place of both temporal and spatial connection to farmers, linking to the broader communities involved in forestry and wood products as well as offering a practised connection to those past and future generations working on the farm. As one arable farmer commented:

'...the forest I sell, the basic work all that has been done by my grandfather...it may take a couple of decades before I can sell anything... the work in the forest that I do, I think someone really get some income for that after 50 or 60 years'

The forest here is positioned as the 'living tissue of time' (Jones, 2011: 162) and so has the capacity to carry memories into the present and beyond through marking, and being marked by, the lives of the farmers going on around it (Cloke and Pawson, 2008). Here, the forest is assembled through the traces of the past embedded in the materiality of the trees, which have been marked by the practices of care shown by this farmer's grandfather, and those being induced by the perceived current needs of the forest and the farmers' sense of responsibility to their descendants. The farmers' experience of a linear timeline connecting them to the past and future, and tethering them in the present, is rooted in the sense of continuity and security offered by the forest (Berglund, 2008) for, as one dairy farmer noted, 'it's continuously there...'. Given the farmers' discussions around forest clearances and the annual felling of particular trees, it is clear that while the components and form may change, the overall assemblage of 'forest' as understood by the farmers continues. However, this perception of stability and the view of the forest as a collective whole, with limited regard to its composition, may hinder efforts to preserve and protect forests. Dairy farms are increasing in size, a common trend across Europe, and while this increases milk production to a more financially 
viable level, it also increases other outputs. Slurry can only be spread in Finland at certain times of year and organic regulations further limit the amount that can be applied to an area. When discussing this challenge, the Evira representative noted that farmers were increasingly resorting to clearing forest simply to have the space to spread manure. This solution is arguably made more feasible because the scale of the Finnish forest lessens the perceived impact that each forest clearance has.

Connections to the past are also reflected in such relations of absence through farmers' personal or familial memories of clearing forest in order to create such new farmland. The existence of particular fields and the practices necessary to maintain them, such as using extra fertilizer or grazing stock to keep trees down, provided an embodied connection to those in the past who had laboured hard to create the farm in its current form. Agricultural landscapes are always haunted by past generations because their practices are still imprinted in contemporary field patterns, buildings, crop rotations, forest clearances and tools that are all the result of decisions taken long ago. 'All the traces of presence of those now absent' (Wylie, 2009: 279) often serve to enforce a narrative of continuity 'with the past being cast as inseparable from forbears who had farmed the same land' (Riley, 2008: 1283).

\section{B. The Forest as a Place of Management}

The forest was also assembled through practices of management; it is not a wilderness but is governed according to accepted criteria laid down by the state that aim for both biodiversity and timber production (Vainio and Paloniemi, 2012). One vegetable farmer positioned working in the forest as a typical activity for Finnish farmers and, while only a few did all the work themselves, the majority undertook the smaller, standard forestry tasks: 
'... when the forest is still young and you can do it manually, you take some of the trees in between but when it's the final harvest ...then the company does that' (Dairy Farmer)

'We do planting ourselves and taking care of the young forest' (Arable Farmer)

The forest therefore emerged in farmers' discussions as a taskscape (Ingold, 1993), which strengthened feelings of embeddedness in the space of the forest-farm through the active construction of, and embodied engagement with, this environment. As well it enabled farmers to practice the social scripts of what it means to be a 'good farmer' in these particular farming communities through engaging with everyday forestry. Even for those for whom the forest only formed a small element of their annual practices, it remained central in shaping their identities for, as one vegetable farmer commented, '...nowadays we don't spend many hours in forest... [but] basically we are forest farm', with even limited time serving to foster a sense of belonging. However, particular discourses regarding the appropriate usage of the forest were hegemonic with only one farmer discussing his desire for conservation. For the others, there was a sense that the forest needed to be managed 'properly' with its critical position within the economy of the farm shaping attitudes towards it:

'I don't have so many big trees left anymore because they was all, the forest was the same age and that's not very good. You should have forest that's different age ... [in a] small forest you have almost every time that trees are same age, when they are cut it takes many ages till next time you get the money...' (Arable Farmer)

However, while this reflects the dominant, productivist discourses surrounding forest management, it also demonstrates the unruly nature of the forest however strictly it may be managed (Cloke and Pawson, 2008). Even managed trees have the capacity to be active agents through offering cover and protection to other species (Griffin, 2010) or the impact of their 
different temporalities on the work patterns of their human companions (Brice, 2014). This farmer could not escape the nature of how the forest grows, which served to frustrate his efforts at maximising economic returns, and so he had to adapt his practices, and projected cash-flow, to the timescales of the trees.

To the industry stakeholders, the management of the forest scaled up beyond these immediate practices, connecting into broader opportunities and debates. Both the MTK and Saimaan Luomu reflected on the growing national and international drives for renewable energy, as discussed in the MMM's (2015) National Forest Strategy 2025, and meeting greenhouse gas emissions targets. The Saimaan Luomu representative noted that in Finland we had a discussion about this, less than 10 years ago, but nowadays I think our focus is changed from the food sector to the forestry sector' in relation to the latter's greater potential as both a renewable energy source and carbon sink. For MTK, as the national strategy in relation to climate change and forestry is further developed, this may change farmers' attitudes towards their forest, with the hope expressed that:

'...it would in a way be entrepreneurship as well because nowadays it's, in a way, the forest is the bank for the farm. When they need to do an investment they are cutting the trees, but they could harvest it more if the aim of renewable energy would go on...'

Although these more macro-scale linkages were not identified by the farmers themselves in this study, through these the forest exerts its capacity to connect farmers into broader national and international projects. In turn this enrols the farmers in additional regulatory requirements, for example around responses to global environmental change, and over time may enforce a change in attitudes and so management practices. 


\section{The Forest as a Place of Economic Security}

Interestingly, the Finnish farmers and industry stakeholders referred to forests only in relation to the economically - or politically - valuable trees, ignoring the other actants in these spaces. Only the farmer interested in conservation recognised the need for diverse forest ecosystems, stating that he wanted:

'...to conserve somehow a part of my forest so I want to...make kind of different kind of forest types with different kind of trees in the same forest so...not like it would be a field of trees but it would be a living, biodiverse forest and then I also want to keep some places that have already like grown forest that would be ready to harvest, I've been thinking to keep them that way and kind of, keep certain areas that would develop in peace to one day be really old, nice forest...' (Vegetable Farmer)

Nevertheless, despite this farmer's desire to not just have a 'field of trees' and recognition of the presence of other actants within the forest assemblage, the continuing economic needs of the farm as a whole still structured his understandings of, and engagements with, the forest for, as he noted:

'... when I make this big investment it was 2008, we made some more cold storage and this packing station, office and social area. Then I was selling wood, forest to finance the project ... and also when we built our own house, I also sold some forest to finance our own home...' (Vegetable Farmer)

This reference to the financial security offered by the forest was common, with - as noted above - many positioning it as a 'bank':

'...it's like money, an account in the bank. It's for the bad days, if you need money suddenly, you can take it from the forest' (Dairy Farmer) 
'... by the naming of the forest as a bank is when you made investments you started by logging your forest, then you would have money to buy, to build a new barn or something... (Evira Representative)

'Forest is little bit extra money to use' (Dairy Farmer)

This reliance on the forest is nothing new, with income disparities between agriculture and other sectors being reduced in the 1980s through the supplementary income offered by forestry (IBP, 2015). As the MMM representative reflected 'the farm incomes from their farm itself has been limited because they have had lots of incomes from the forest and for a long time they have diversified to other areas...'. Diversification in general has therefore always been an economic strategy for Finnish farmers with those in my study also engaging in tourism, education, a farm shop, handicrafts, machine rental and municipal snow ploughing. Interestingly, as Figure 1 shows, forestry actually represents a decreasing proportion of farm income (2000-2010). This is arguably due to the structural reform in Finnish agriculture post1995, when Finland joined the EU, with more farms becoming 'part-time' and so increasingly reliant on waged income as opposed to the more traditional but time-consuming forestry work (Hilden et al., 2012; Puurunen and Vare, 2002). In turn, this change in owner characteristics has, Suuriniemi et al. (2012) argue, also diversified their objectives with conservation and recreation increasingly valued. 


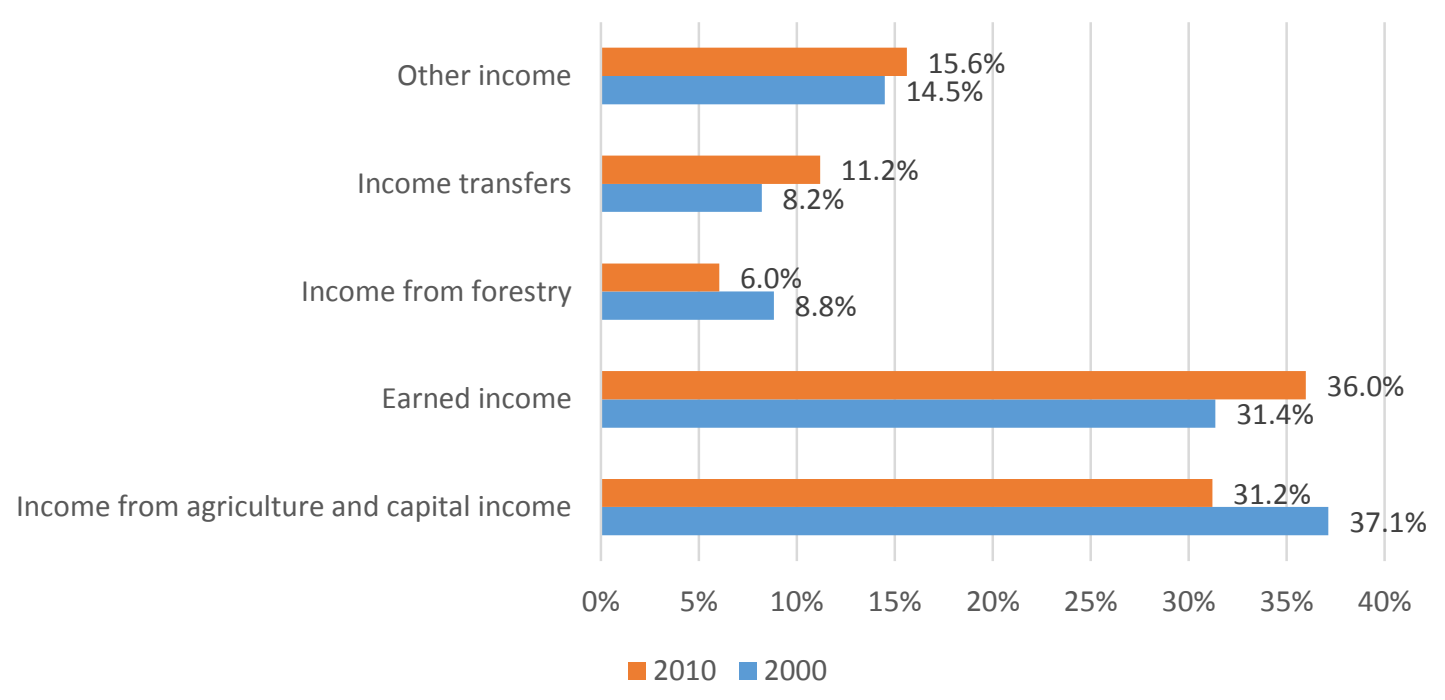

Figure 1 Farmers Dependence on Forestry as Part of Overall Income. Source: Statistics Finland (2012)

Nonetheless, despite this empirical evidence, the rhetoric around the economic significance of the forest persists, and in the farmers' accounts of their everyday practices it loomed larger than any other income-generating activity. This is arguably because of the role of the forest in the dominant social scripts of Finnish national and agricultural identity. It embeds the farmers of this case study in the particular places of their farms through their continual, embodied practice of managing the trees, which in turn offer economic returns through lumber, heating material for the farmhouse or as a source of traditional bark-based handicrafts.

These three ways in which the Finnish forest was composed were held in place through the embodied experiences and practised discourses that performed the 'forest'. They are not the only possible assemblages and are not exclusive, with those components that offer temporal connections entering into different relations to also be understood as opportunities for management or economic security. The forest therefore emerges as a fluid and ongoing process, an open place that is constantly in formation (Anderson et al., 2012). So, how do these different compositions shape the resilience of their farm communities? 
As Burton (2004: 210) argues landscapes are '4D portraits of the incumbent farming family', with the nature of farming allowing for collective, symbolic displays of skill, identity and commitment across generations. Like the livestock discussed earlier, the forest has the capacity to link the present to the past and future, which offers a valuable, longitudinal connection to the place of the farm, embedding and strengthening the people-place connections recognised as critical to social resilience (Berkes and Ross, 2013; Maclean et al., 2014; Wilson, 2015). The long time-scales that engaging in this production system entailed, with an average production cycle of around 100 years, also inflected the everyday thinking of the farmers. While this was shaped by the daily, seasonal or annual rhythms of, for example, cabbage or beef production, the need to also think across decades fostered long-term planning for the farm more generally; this encouraged resilient practices through getting farmers to articulate a future imaginary of their farm to work towards. However, these long time frames also offer a challenge. While forest-farmers have always had uncertainty in terms of how to manage the forest given that the results of their labour will only be seen in a century, the contemporary backdrop of global environmental change has foregrounded this question through the increased agri-environmental demands of regulators to adapt to, and mitigate, this unknown future.

Through its capacity to connect, temporally and spatially, and composition as a fundamentally practised space, the forest is also enabled as a repository of, and space to develop, knowledge and skills, as well as offering an opportunity to maintain a diverse farm economy - further elements of a resilient community (Maclean et al., 2014). However, it is the dominant economic focus which pervaded farmers' accounts, which I argue highlights both the social scripts around being a 'good forest-farmer' as well as the exclusions that these particular constructions of the forest as managed, economically important and connective assemblages enact. Farmers here conflated the forest with trees alone fostering the collective rather than individual approach advocated by Bear 
(2011) and Head and Atchison (2008). It is only through volume that the forest is economically significant - individual trees may be considered as particularly fine timber, as unruly or as requiring removal but this is always within the context of 'care' for the forest as a whole:

'I have to go cut the wrong trees away and just leave the best ones' (Arable Farmer)

'...cutting the kind of other branches and trees off to leave space for the certain type of wood which we want to grow' (Beef Farmer)

These discussions highlight the normative discourses around 'good' and 'bad' trees that inflect these farmers' engagements with the forest. Through this we can begin to see the exclusions perpetuated with non-desirable trees, other plants, birds, animals and insects relatively silent, at least until their presence becomes visible through the destruction or subversion of the farmers' management strategies.

Forests also appeared as socially exclusionary, being particularly gendered landscapes with forestry positioned as 'man's work' (Evira Representative); as one farmer noted with pride 'my husband is expert in forest things' (Dairy Farmer). This is grounded in the modernist development of the national forestry sector in Finland, inspired by visions of human control over nature (Kotilainen and Rytteri, 2011), which in themselves represent certain gendered relations of domination (Cloke and Pawson, 2008). It led on to the forest being positioned as a space of psychological retreat with the dairy farmer continuing, 'forest is a little bit his hobby... it's very good for your health to work in the forest, mental health'. The practical nature of the work, the delegation of heavy jobs to contractors and the embodied sense of being in the forest combined with the enforced slow time frames served to foster a more relaxed attitude. In contrast to the pressures of responding to retailer orders, the demands placed by the trees were more manageable; as one beef farmer noted 'I have 197ha of forest and I manage by myself... one tree 
grows 90 years so I have enough time!' While forests provide a backdrop for a range of practices including berry collecting, mushroom picking, walking, fishing, hunting and skiing, these were not mentioned by the farmers, and their emphasis on forestry establishes this as a traditional, male taskscape centred around particular tree species rather than a more inclusive space. I suggest that the continuity and expression of a particular farming self offered by the forest can act negatively with the past serving as a compass in the performance of current practices (Riley, 2008) including patriarchical relations, restricting innovation and constraining agency. The feeling of being responsible to the ghosts of the past can reduce farmers' ability to make their own management decisions (Lähdesmäki and Matilainen, 2014).

Through a range of interconnected and multi-scalar relations and practices, forests serve to connect these particular farm communities across time and space through embedding individuals in familial or communal spaces, fostering a sense of national identity and engaging the farmers in embodied taskscapes. The forests and their constituent elements are active agents in shaping the places, relations and practices that form the more-than-human assemblages of these Finnish farms; their cycles of growth and decay can serve to strengthen social resilience through providing beneficial economic, cultural and natural resources (Wilson, 2015), as well as enhancing farmers' connection to the place of their farm (Berkes and Ross, 2013; Magis, 2010). However, through the different attitudes farmers demonstrated towards the management of their forests, and glimpses of the active yet unintentional agency of the trees and other nonhuman actants, we can see that these are dynamic and highly contextual systems. For one forest, rodent pests might be an issue (Griffin, 2010), while in others invasive plant species, insects or pathogens may be significant actants; furthermore, the 'ideal' forest striven for will be shaped by different cultural scripts and its achievement impacted by varying weather and climate systems. Therefore, while the forest assemblage may offer the potential to enhance the resilience of a farm or rural community, 
impacts are always ultimately unpredictable (Berkes and Ross, 2013). The resilience of the farm requires a constant performance to ensure that this relational assemblage comes together in resilient ways; these will be different depending on the particular spaces, places, actants, relations and practices of the farm and so demands that we acknowledge the multiplicity of possible resiliences.

\section{Conclusions}

A more-than-human focus on social resilience opens out this concept to acknowledge its uneven, contextual, multiple, relational and practised nature. Through the expanding view of the social presented by more-than-human literatures, communities emerge as entangled, interdependent and relationally constituted assemblages of both human and nonhuman actants. Recognising the active, but not intentioning, subjectivity of the nonhumans within these relocates agency in praxis, with it becoming an emergent, relational property of the network. The individual therefore becomes decentred and instead their positioning within an interconnected assemblage is foregrounded. In turn this demands that - since a resilient community needs to be constituted of resilient actants - we must be responsive to all the relations, whether positive or negative, of connection or detachment, that constitute the networks we are constituted by. Furthermore, all needs and capabilities must be supported or enhanced, given their potential impact on the resilience or vulnerability of the community as a whole. Resilience therefore becomes not a process of individual responsibilisation but embedded in, and emergent from, the practices that maintain the networks of relationality that we form, and are formed by (Puig de la Bellacasa, 2010). 
The forest was a key part of an explicitly Finnish farmer identity but it also simultaneously fell into the background as simply part of the broader, 'taken for granted' farmscape. This was disrupted by the unintentioning but unruly bodies of the trees themselves or the other flora and fauna of the forest, the imprints left by the past or the economic imperative of financial needs elsewhere on the farm; then, the forest was foregrounded, providing and stabilising the sense of community, connections to place and natural resources that are all critical elements within community resilience. The communities the forest connected to were both spatial and temporal, linking farmers to collective, national identities as well as familial ones through connections both to the past, present and future. The forest offered a reassuring sense of continuity, and interactions with it allowed for an embodied experience of belonging as well as being in the forest, which was inscribed with the practices of past years and generations. However, despite offering significant socio-cultural, economic and environmental support to the resilience of the farm-community, uneven power relations between, in particular, the human and nonhuman actants continued. The forest emerged as a collective but exclusive space, in which trees were only individually identified through a normative assessment of 'usefulness', with those species that were not economically valuable not being allowed to flourish. This has potential implications for the future resilience of the forest farm if its biodiversity is reduced to such an extent that economically limiting and environmentally unsustainable monocultures redefine how the forest is understood and produced.

As Folke at al (2003) note change, not stasis, is the constant in social systems and through the focus on the relational networks of these Finnish forest-farms we can see that they are constant works in progress, and must continuously be performed through, in this instance, forestry in order to iteratively persist. Given the diversity in types of forest, climate, weather, soil, flora and fauna, alongside the nature of the farm, farmer and all the other human and nonhuman actants in the 
assemblages that constitute them, we can see that resilience can never be practised in the same way. Instead, it is fractured and multiple, dependent on the relations between the actants within a particular space or community. This opens up resilience to the whole host of actants who, importantly, are already and have long been active agents within it. This contextuality disrupts attempts to operationalise resilience beyond a local scale, and highlights the need for continuing theoretical and empirical development in order to be able to comparatively measure resilience, and so transfer the 'best practice' that would enhance the socio-ecological resilience of vulnerable communities. Within this, greater recognition also needs to be given to the constraints and opportunities offered by the relationships with, and between, nonhuman actants. To achieve this, more work is needed to engage in depth with communities in order to understand the role, relations and impacts of the nonhuman in developing more-than-human resiliences.

While focusing here on agricultural systems, the debates in this paper also connect into broader contemporary discussions around the nature and relevance of resilience, how it may be promoted and who is affected/excluded by resilience strategies (Adger and Nelson, 2010; Bourbeau, 2015; Fainstein, 2015; Levine et al., 2012) in addition to debates around farming systems (see, for example, Forney and Stock, 2014; Stock and Forney, 2014) and posthuman/more-than-human geographies. Reflecting on Diprose's (2014) concerns around the individualisation and inequalities of resilience, I argue that recognising the social as co-fabricated and co-constituted fosters a more just resilience within a locality through demanding that we bolster the resilience of all the actants - human and nonhuman - within that assemblage. In turn, through the more-than-human reconceptualization of agency, this arguably bridges the socio-ecological divide that persists in resilience thinking through encouraging the recognition that we are all active and entangled actants. 


\section{References}

Adger, W.N., 2000. Social and Ecological Resilience: are they related? Progress in Human Geography 23, 347-364.

Adger, W.N., Brown, K., Nelson, D.R., Berkes, F., Eakin, H., Folke, C., Galvin, K., Gunderson, L., Goulden, M., O'Brien, K., Ruitenbeek, J., Tompkins, E.L., 2011. Resilience implications of policy responses to climate change. Wiley Interdisciplinary Review: Climate Change 2 (5), 757-766.

Adger, W.N., Nelson, D., 2010. Fair decision making in a new climate of risk, in: O'Brien, K., St. Clair, A., Kristoffersen, B. (Eds.), Climate Change, Ethics and Human Security. Cambridge University Press:, Cambridge, pp. 83-94.

Aldrich, D.P., Meyer, M.A., 2015. Social Capital and Community Resilience. American Behavioral Scientist 59 (2), 254-269.

Alston, M., 2012. Rural Male Suicide in Australia. Social Science and Medicine 74, 515-522.

Anderson, B., 2015. What Kind of Thing is Resilience? Politics 35 (1), 60-66.

Anderson, B., Kearnes, M., McFarlane, C., Swanton, D., 2012. On Assemblages and Geography. Dialogues in Human Geography 2 (2), 171-189.

Barnett, C., Cloke, P., Clarke, N., Malpass, A., 2005. Consuming Ethics: articulating the subjects and spaces of ethical consumption. Antipode 37, 23-45.

Bear, C., 2011. Being Angelica? Exploring Individual Animal Geographies. Area 43 (3), 297-304.

Bennett, J., 2004. The Force of Things: steps toward an ecology of matter. Political Theory 32 (3), 347-372.

Berglund, E., 2008. Forest, Flows and Identities in Finland's Information Society. Cultural Studies 22 (3-4), 412-430.

Berkes, F., Ross, H., 2013. Community Resilience: towards an integrated approach. Society and Natural Resources 26, 5-20.

Björklund, J., Araya, H., Edwards, S., Goncalves, A., Höök, K., Lundberg, J., Medina, C., 2012. EcosystemBased Agriculture Combining Production and Conservation - a viable way to feed the world in the long term? Journal of Sustainable Agriculture 36 (7), 824-855.

Bourbeau, P., 2015. Resilience and International Politics: premises, debates, agenda. International Studies Review.

Brassett, J., Croft, S., Vaughan-Williams, N., 2013. Introduction: an agenda for resilience research in politics and international relations. Politics 33 (4), 221-228.

Brice, J., 2014. Attending to Grape Vines: perceptual practices, planty agencies and multiple temporalities in Australian viticulture. Social \& Cultural Geography 15 (8), 942-965.

Buciega, A., Pitarch, M.-D., Esparcia, J., 2009. The Context of Rural-Urban Relationships in Finland, France, Hungary, The Netherlands and Spain. Journal of Environmental Policy \& Planning 11 (1), 9-27. 
Burton, R.J.F., 2004. Seeing through the 'Good Farmer's' Eyes: towards developing an understanding of the social symbolic value of 'productivist' behaviour. Sociologia Ruralis 44 (2), 195-215.

Burton, R.J.F., 2012. Understanding Farmers' Aesthetic Preference for Tidy Agricultural Landscapes: a Bourdieusian perspective. Landscape Research 37 (1), 51-71.

Cadieux, K.V., Blumberg, R., 2013. Food Security in Systemic Context, in: Thompson, P., Kaplan, D.M. (Eds.), Encyclopedia of Food and Agricultural Ethics. Springer, London.

Chandler, D., 2013. Resilience Ethics: responsibility and the globally embedded subject. Ethics \& Global Politics 6 (3), 175-194.

Cloke, P., Pawson, E., 2008. Memorial Trees and Treescape Memories. Environment and Planning D 26, 107-122.

Convery, I., Bailey, C., Mort, M., Baxter, J., 2005. Death in the Wrong Place? Emotional Geographies of the UK 2001 Foot and Mouth Disease Epidemic. Journal of Rural Studies 21, 99-109.

Coward, M., 2015. Editor's Introduction: resilience revisited. Politics 35 (1), 58-59.

Cudworth, E., Hobden, S., 2015. Liberation for Straw Dogs? Old Materialism, New Materialism, and the Challenge of an Emancipatory Posthumanism. Globalizations 12 (1), 134-148.

Day, J.M., 2014. Fostering Emergent Resilience: the complex adaptive supply network of disaster relief. International Journal of Production Research 52 (7), 1970-1988.

DeLanda, M., 2006. A New Philosophy of Society: assemblage theory and social complexity. Continuum, London.

Diprose, K., 2014. Resilience is Futile: the cultivation of resilience is not an answer to austerity and poverty. Soundings (58), 44-56.

Dixon, D., 2009. Creating the Semi-Living: on politics, aesthetics and the more-than-human. Transactions of the Institute of British Geographers 34, 411-425.

Dwiartama, A., Rosin, C., 2014. Exploring Agency Beyong Humans: the compatibility of Actor-Network Theory (ANT) and resilience thinking. Ecology and Society 19 (3), 28.

Eurostat, 2013. Agricultural Census 2010 - main results. Eurostat.

Evans, B., Reid, J., 2013. Dangerously Exposed: the life and death of the resilient subject. Resilience: International Policies, Practices and Discourses 1 (2), 83-98.

Fainstein, S., 2015. Resilience and Justice. International Journal of Urban and Regional Research 39 (1), 157167.

Folke, C., 2006. Resilience: the emergence of a perspective for social-ecological systems analyses. Global Environmental Change 16, 253-267.

Folke, C., Carpenter, S.R., Walker, B., Scheffer, M., Chapin, T., Rockstrom, J., 2010. Resilience Thinking: integrating resilience, adaptability and transformability. Ecology and Society 15 (4), 20. 
Folke, C., Coldling, J., Berkes, F., 2003. Synthesis: building resilience and adaptive capacity in socialecological systems, in: Berkes, F., Coldling, J., Folke, C. (Eds.), Navigating Social-Ecological Systems: building resilience for complexity and change. Cambridge University Press, Cambridge, pp. 329-352.

Forney, J., Stock, P.V., 2014. Conversions of Family Farms and Resilience in Southland, New Zealand. International Journal of the Sociology of Agriculture and Food 21 (1), 7-29.

Ginn, F., 2014. Sticky Lives: slugs, detachment and more-than-human ethics in the garden. Transactions of the Institute of British Geographers 39, 532-544.

Gray, J., 1996. Cultivating Farm Life on the Borders: Scottish hill sheep farms and the European community. Sociologia Ruralis 36, 27-50.

Greenhill, J., King, D., Lane, A., MacDougall, C., 2009. Understanding Resilience in South Australian Farm Families. Rural Society 19 (4), 318-325.

Griffin, C.J., 2010. More-than-human Histories and the Failure of Grand State Schemes: sylviculture in the New Forest, England. Cultural Geographies 17 (4), 451-472.

Hall, P.A., Lamont, M., 2013. Social Resilience in the Neoliberal Era. Cambridge University Press, Cambridge.

Hammond, B., Berardi, G., Green, R., 2013. Resilience in Agriculture: small- and medium-sized farms in Northwest Washington State. Agroecology and Sustainable Food Systems 37 (3), 316-339.

Head, L., Atchison, J., 2008. Cultural Ecology: emerging human-plant geographies. Progress in Human Geography, 1-10.

Head, L., Muir, P., 2006. Suburban Life and the Boundaries of Nature: resilience and rupture in Australian backyard gardens. Transactions of the Institute of British Geographers 31 (4), 505-524.

Hietala-Koivu, R., 2002. Landscape and Modernizing Agriculture: a case study of three areas in Finland in 1954-1998. Agriculture, Ecosystems and Environment 91, 273-281.

Hilden, M., Jokinen, P., Aakkula, J., 2012. The Sustainability of Agriculture in a Northern Industrialized Country - from controlling nature to rural development. Sustainability 4, 3387-3403.

Holloway, L., 2001. Pets and Protein: placing domestic livestock on hobby-farms in England and Wales. Journal of Rural Studies 17, 293-307.

Holloway, L., 2002. Smallholding, hobby-farming, and commercial farming: ethical identities and production of farming spaces. Environment and Planning A 34, 2055-2070.

Holloway, L., Morris, C., 2014. Viewing Animal Bodies: truths, practical aesthetics and ethical considerability in UK livestock breeding. Social \& Cultural Geography 15 (1), 1-22.

Howell, A., 2015. Resilience as Enhancement: governmentality and political economy beyond 'responsibilisation'. Politics 35 (1), 67-71.

Hunt, W., Vanclay, F., Birch, C., Coutts, J., Flittner, N., Williams, B., 2011. Agricultural Extension: building capacity and resilience in rural industries and communities. Rural Society 20 (2), 112-127.

Hyttinen, P., Kola, J., 1995. Farm Forests and Rural Livelihood in Finland. Journal of Rural Studies 11 (4), 387-396. 
IBP, 2015. Finland Investment and Business Guide. International Business Publications, Washington DC.

Ingold, T., 1993. The Temporality of the Landscape. World Archaeology 25 (2), 152-174.

Johnston, C., 2008. Beyond the clearing: towards a dwelt animal geography. Progress in Human Geography $32(5), 633-649$.

Jones, O., 2011. Materiality and Identity: forests, trees and senses of belonging, in: Ritter, E., Dauksta, D. (Eds.), New Perspectives on People and Forests. Springer, London, pp. 159-177.

Jones, O., Cloke, P., 2002. Tree Cultures: the place of trees and trees in their place. Berg, Oxford.

Joseph, J., 2013. Resilience as Embedded Neoliberalism: a governmentality approach. Resilience: International Policies, Practices and Discourses 1 (1), 38-52.

Keck, M., Sakdapolrak, P., 2013. What is Social Resilience? Lessons Learned and Ways Forward. Erdkunde 67 (1), 5-19.

Kotilainen, J., Rytteri, T., 2011. Transformation of Forest Policy Regimes in Finland since the 19th Century. Journal of Historical Geography 37, 429-439.

Krarup, T., Blok, A., 2011. Unfolding the Social: quasi-actants, virtual theory, and the new empiricism of Bruno Latour. The Sociological Review 59 (1), 42-63.

Krøvel, R., 2014. Social Production of Community Resilience. Resilience: International Policies, Practices and Discourses 2 (1), 64-70.

Lähdesmäki, M., Matilainen, A., 2014. Born to be a forest owner? An empirical study of the aspects of psychological ownership in the context of inherited forests in Finland. Scandinavian Journal of Forest Research 29 (2), 101-110.

Latimer, J., 2013. Being 'Alongside': Rethinking relations amongst different kinds. Theory, Culture \& Society 30 (7-8), 77-104.

Latimer, J., Miele, M., 2013. Naturecultures? Science, Affect and the Non-human. Theory Culture Society, 127.

Latour, B., 1993. We Have Never Been Modern. Harvard University Press, Cambridge, MA.

Latour, B., 1999. Pandora's Hope: essays on the reality of science studies. Harvard University Press, Cambridge, MA.

Latour, B., 2005. Reassembling the Social: an introduction to actor network theory. Oxford University Press, Oxford.

Lawson, V., 2007. Geographies of Care and Responsibility. Annals of the Association of American Geographers 97, 1-11.

Levine, S., Pain, A., Bailey, S., Fan, L., 2012. The Relevance of 'Resilience', HPG Policy Brief. Humanitarian Policy Group.

Lin, B.B., 2011. Resilience in Agriculture through Crop Diversification: adaptive management for environmental change. BioScience 61 (3), 183-193. 
Maclean, K., Cuthill, M., Ross, H., 2014. Six Attributes of Social Resilience. Journal of Environmental Planning and Management 57 (1), 144-156.

Magis, K., 2010. Community Resilience: an indicator of social sustainability. Society and Natural Resources 23, 401-416.

Maleksaeidi, H., Karami, E., 2013. Social-Ecological Resilience and Sustainable Agriculture under Water Scarcity. Agroecology and Sustainable Food Systems 37 (3), 262-290.

Marshall, N.A., Park, S.E., Adger, W.N., BRown, K., Howden, S.M., 2012. Transformational Capacity and the Influence of Place and Identity. Environmental Research Letters 7, 1-9.

Mason, G., Pulvirenti, M., 2013. Former Refugees and Community Resilience: 'papering over' domestic violence. British Journal of Criminology 53, 401-418.

Massey, D., 2004. Geographies of Responsibility. Geografiska Annaler 86 (B), 5-18.

McDonagh, J., 2012. Rural Geography 1: changing expectations and contradictions in the rural. Progress in Human Geography, 1-9.

Metzger, J., 2014. Commentary: spatial planning and/as caring for more-than-human place. Environment and Planning A 46, 1001-1011.

MMM, 2007. Finland's Northern Conditions: challenges and opportunities for agriculture. MMM, Helsinki.

MMM, 2011. Farming and Food in Finland. MMM, Helsinki.

MMM, 2013. The CAP after 2013. MMM, Helsinki.

MMM, 2015. National Forest Strategy 2025. MMM, Helsinki.

Morton, T., 2010. The Ecological Thought. Harvard University Press, Cambridge, MA.

Müller, M., 2015. Assemblages and Actor-Networks: rethinking socio-material power, politics and space. Geography Compass 9 (1), 27-41.

Nimmo, R., 2011. Actor-Network Theory and Methodology: social research in a more-than-human world. Methodological Innovations Online 6 (3), 108-119.

Panelli, R., 2010. More-than-Human Social Geographies: posthuman and other possibilities. Progress in Human Geography 34 (1), 79-87.

Pentikainen, J., 1995. The Forest Finns as Transmitters of Finnish Culture from Savo via Central Scandinavia to Delaware, in: Hoffecker, C.E. (Ed.), New Sweden in America. Associated University Presses, pp. 291-301.

Phillips, C., 2014. Following Beekeeping: more-than-human practice in agrifood. Journal of Rural Studies 36, 149-159.

Popke, J., 2006. Geography and Ethics: everyday mediations through care and consumption. Progress in Human Geography 30 (4), 504-512.

Pouta, E., Myyrä, S., Hänninen, H., 2011. Farm Landowners' Objectives in Finland: two approaches for owner classifications. Society and Natural Resources 24 (10), 1042-1062. 
Puig de la Bellacasa, M., 2010. Ethical Doings in Naturecultures. Ethics, Place \& Environment 13 (2), 151169.

Puurunen, M., Vare, M., 2002. Total incomes of Farm Families in Finland, Workshop on the Farm Household-Firm Unit, Imperial College, University of London.

Ranjan, R., 2014. Multi-Dimensional Resilience in Water-Scarce Agriculture. Journal of Natural Resources Policy Research 6 (2-3), 151-172.

Reid, J., 2012. The Disastrous and Politically Debased Subject of Resilience. Development Dialogue (58), 6780 .

Riley, M., 2008. Experts in their Field: farmer-expert knowledges and environmentally friendly farming practices. Environment and Planning A 40, 1277-1293.

Riley, M., 2011. 'Letting Them Go' - Agricultural Retirement and Human-Livestock Relations. Geoforum 42, 16-27.

Robinson, L.W., Berkes, F., 2011. Multi-Level Participation for Building Adaptive Capacity: formal agencycommunity interactions in northern Kenya. Global Environmental Change 21, 1185-1194.

Rogers, P., 2013. Rethinking Resilience: articulating community and the UK riots. Politics 33 (4), 322-333.

Sarkki, S., Rönkä, A.R., 2012. Neoliberalisations in Finnish Forestry. Forest Policy and Economics 15, 152159.

Schmidt, J., 2013. The Empirical Falsity of the Human Subject: new materialism, climate change and the shared critique of artifice. Resilience: International Policies, Practices and Discourses 1 (3), 174-192.

Sellick, J., Yarwood, R., 2013. Placing Livestock in Landscape Studies: pastures new or out to graze? Landscape Research 38 (4), 404-420.

Silvasti, T., 2003a. The Cultural Model of 'The Good Farmer' and the Environmental Question in Finland. Agriculture and Human Values 20, 143-150.

Silvasti, T., 2003b. Bending Borders of Gendered Labour Division on Farms: the case of Finland. Sociologia Ruralis 43 (2), 154-166.

Solsten, E., Meditz, S.W., 1988. Finland: a country study. Library of Congree, Washington.

Statistics Finland, 2012. Only Every Third Euro of a Farmer's Income Came From Agriculture in 2010. http://www.stat.fi/til/mmtal/2010/mmtal 2010 2012-03-30 tie 001 en.html.

Stock, P.V., Forney, J., 2014. Farmer Autonomy and the Farming Self. Journal of Rural Studies 36, 160-171.

Suuriniemi, I., Matero, J., Hanninen, H., Uusivuori, J., 2012. Factors Affecting Enlargement of Family Forest Holdings. Silva Fennica 46 (2), 253-266.

Vainio, A., Paloniemi, R., 2012. Forest Owners and Power: a Foucauldian study on Finnish forest policy. Forest Policy and Economics 21, 118-125.

Väre, M., 2007. Determinants of Farmer Retirement and Farm Succession in Finland, Faculty of Agriculture and Forestry. University of Helsinki. 
Wilson, G.A., 2010. Multifunctional 'Quality' and Rural Community Resilience. Transactions of the Institute of British Geographers 35 (3), 364-381.

Wilson, G.A., 2015. Community Resilience and Social Memory. Environmental Values 24, 227-257.

Wylie, J., 2009. Landscape, Absence and the Geographies of Love. Transactions of the Institute of British Geographers 34, 275-289.

Yarwood, R., Evans, N., 2006. A Lleyn Sweep for Local Sheep? Breed Societies and the Geographies of Welsh Livestock. Environment and Planning A 38, 1307-1326.

Zhang, Y., Hussain, A., Deng, J., Letson, N., 2007. Public Attitudes Towards Urban Trees and Supporting Urban Tree Programs. Environment and Behavior 39 (6), 797-814. 